\title{
Computer Visual Measurement Technology and Algorithm Simulation for the Assembly of Large Aircraft Parts
}

\author{
Qiong Liu ${ }^{1}$, YouRong Yan $^{2}$, LeiLei Cao ${ }^{1}$ \\ ${ }^{1}$ Expressway Roadbuilding Equipment \&Technology Research Center, Chang'an University, Mailbox 322, Cuihua Road, \\ Yanta District, Xi'an ShaanXi 710064, China. E-mail: 18909290986@163.com, 48062164@qq.com \\ ${ }^{2}$ Xi'an Precision Machinery Research Institute, Psalmi 705 Institute, Gaoxin Road, Yanta District, Xi'an, ShaanXi 710075, \\ China. E-mail: yanyr3975@sina.com
}

This research aims to solve the issues of limited measuring range and great accumulative error in the digital assembly of aircraft parts. In this paper, we propose the use of array visual measurement technology for the assembly of large aircraft parts. First, the visual measurement space for large aircraft parts assembly is determined. Second, the visual measurement model for large aircraft parts is constructed. Then, the differences that occur in real-time to the global coordinates can be calculated by using the pre-assembly feature points of large parts and the measurement tools of an array visual system. Finally, the real-time simulation of the aircraft assembly process is conducted in ADAMS by the secondary development of the software. In addition, errors between the real-time assembly and the design model are solved, and then transmitted to the mechanical actuators, which in turn adjust their attitude to complete the assembly of the large aircraft parts. The results show that array visual measurement technology for the assembly of large aircraft parts is feasible and efficient.

Keywords: Aircraft Digital Assembly, Vision Measuring, Spatial Transformation, ADAMS, Motion Simulation

\section{Acknowledgement}

This research is supported by Fundamental Research Funds for the Central Universities (2014G1251032), Natural Science Foundation of Shaanxi Province (2012JQ1008) and the Special Fund for Basic Scientific Research of Central Colleges (2013G2251007). The authors gratefully acknowledge the partial support from Expressway Roadbuilding Equipment \& Technology Research Center, and ShaanXi Engineering \& Technology Research Center of Special Digital Manufacturing Equipment.

\section{References}

[1] MUElaner, J. E., MARTiN, O. C., MAROPOUlOS, P. G. (2013). Achieving Low Cost and High Quality Aero Structure Assembly through Integrated Digital Metrology Systems, Proceedings of Manufacturing. Vol. 7, No. 1, pp. 688-693, TTP. Switzerland.

[2] FEN, W. H., QIANG, N. F. (2012). Key Technologies of Digital Pre-assembly in Networked Collaborative Design and Manufacturing, Mechatronics and Applied Mechanics, Vol. 157, No. 158, pp. 171-174.Spinger.

[3] ZOU, J. H., LIU, Z., FAN. Y. (2007). Large size airplane parts digital assembly technology, Computer Integrated Manufacturing Systems, Vol. 13, No. 7, pp. 1367-1373. Elsevier.

[4] EROHIN, O., KUHLANG, P., SCHALlOW, J., DEUSE, J. (2012). Intelligent Utilisation of Digital Databases for Assembly Time Determination in Early Phases of Product Emergence, Procedia CIRP, Vol. 3, No. 7, pp. 424429. Elsevier.

[5] JIN, L., XIAO, Z., LIU., J. (2009). Study on the Technologies of Rapid Three-dimensional Optical Measurement and Modeling for Large Airplane, Chinese Journal of Aeronautics. Vol. 20, No. 6, pp. 648-656. Ei Cimpendex.

[6] LÄMKULL, D., HANSON, L., ÖRTENGREN, R. (2009). A comparative study of digital human modelling simulation results and their outcomes in reality: A case study within manual assembly of automobiles, International Journal of Industrial Ergonomics, Vol. 39, No. 2, pp. 428-441. Spinger.

[7] QIN, L. G., CHENG, Y., YAO, D. (2008). Advanced Positioning Technology for Aircraft Assembly, Aeronautical Manufacturing Technology. Vol. 41, No. 10, pp. 1167-1171. Spinger.

[8] BLEY, H., FRANKE, C. (2004). Integration of Product Design and Assembly Planning in the Digital Factory, CIRP Annals - Manufacturing Technology, Vol. 53, No. 1, pp. 25-30. ASME, New York.

[9] PAPAKOSTAS, N., ALEXOPOULOS, K., KOPANAKIS, A. (2011). Integrating digital manufacturing and simulation tools in the assembly design process: A cooperating robots cell case, CIRP Journal of Manufacturing Science and Technology, Vol. 4, No. 1, pp. 96-100. ASME, New York.

[10] LUKOVICS, P. (2013). Evaluation of vibration on technological devices. In: Manufacturing Technology, Vol. 14, No. 3, pp. 345-349. 